\title{
Population genetics of an opportunistic parasitoid in an agricultural landscape
}

\author{
TY T. VAUGHN* \& MICHAEL F. ANTOLIN \\ Department of Biology, Colorado State University, Fort Collins, CO 80523, U.S.A.
}

\begin{abstract}
Parasitoid insects that use different hosts can have a subdivided population structure that corresponds to host use. A subdivided population structure may favour local adaptation of subpopulations to small-scale environmental differences and may promote their genetic divergence. In this paper, heritable Random Amplified Polymorphic DNA (RAPD) markers visualized by single strand conformational polymorphisms (SSCP) analysis were used to examine the population structure of the parasitoid wasp Diaeretiella rapae (Hymenoptera: Braconidae) in an environment where two aphid hosts are available for oviposition. We found 11 codominant and 34 dominant RAPD polymorphisms that conformed to Mendelian segregation patterns. A nested analysis of variance indicated extensive genetic differentiation among six populations of D. rapae that were sampled for two years. Effective migration rates $(\mathrm{Nm})$ between populations ranged from 1.2-1.6 per year, indicating a relatively low dispersal rate. Genetic distances were also calculated between populations and the resulting trees indicated that populations less than $1.0 \mathrm{~km}$ from each other were genetically differentiated. Our results indicate that $D$. rapae populations are genetically subdivided on a small spatial scale that corresponds to host-use patterns.
\end{abstract}

Keywords: biological control, Diaeretiella rapae, gene flow, parasitoid, population structure, RAPD-PCR.

\section{Introduction}

Nearly all species of plants and animals display genetic differentiation at some geographical scale, usually as a result of habitat discontinuity, habitat fidelity or limited dispersal. In some cases, local environmental variation may cause natural selection to operate differently among populations, leading to genetic differentiation (Via, 1994). The evolutionary forces responsible for creating genetic differentiation among populations are limited migration, small local population sizes, restricted matings and selection within a population (Endler, 1986; Hartl \& Clark, 1989; Rank, 1992; Roderick, 1996). Dispersal of individuals into other populations can ameliorate these effects by increasing gene flow among populations (Slatkin, 1987, 1994). Therefore, the presence of population structuring indicates that one or more of these forces may be operating.

*Correspondence: Department of Anatomy and Neurobiology, Washington University School of Medicine, 660 South Euclid Avenue, St. Louis, MO 63110, U.S.A. E-mail: vaughnt@thalamus.wustl.edu
Identifying the forces responsible for genetic differentiation of populations is of interest to evolutionary biologists; it is also important to practitioners of biological control. Biological control theory predicts that useful natural enemies will have high dispersal rates compared to their prey or hosts, especially in heterogeneous environments (van Emden, 1974; Murdoch, 1990; Roderick, 1992). This implies that the most successful natural enemies should not form local subpopulations but should remain panmictic. Despite the recognized importance of natural enemy mobility, little is known about their population structure or about the rates of gene flow between local populations of predators and parasitoids (Hopper et al., 1993; Roderick, 1996).

One of the problems in the analysis of population structure is determining the amount of gene flow between populations. It is usually impossible to detect individual insects moving long distances (but see Antolin \& Strong, 1987), therefore we must rely on indirect measures such as DNA markers to infer gene flow (Roderick, 1996). Historically, the majority of gene flow analyses have examined protein 
polymorphisms (allozyme markers) to describe allele frequency variation in time and space. However, allozymes may not provide adequate resolution for determining migration patterns because of low mutation rates and selection acting to limit variability of protein allozymes (Avise, 1994). In addition, Hymenoptera have exceptionally low allozyme variability (Graur, 1985). Recent developments of molecular genetic markers that detect DNA-level variability have increased the power of insect population genetic studies (Avise, 1994; Haymer, 1994; Roderick, 1996). We have developed and enhanced the use of Randomly Amplified Polymorphic DNA amplified by the Polymerase Chain Reaction (RAPD-PCR) to generate repeatable and heritable markers useful in molecular taxonomy, genome mapping and population genetics (Hiss et al., 1994; Antolin et al., 1996a,b).

In this study, RAPD-PCR markers were used in conjunction with single strand conformation polymorphism (SSCP) analysis to examine the population structure of the parasitoid wasp Diaeretiella rapae M'Intosh (Hymenoptera: Braconidae). Diaeretiella rapae is a parasitoid of many aphid species that feed on various plant types but it is commonly found parasitizing aphids that feed on cruciferous plants. In previous studies, we found that $D$. rapae is primarily attracted to cruciferous plant odours (Vaughn et al., 1996). However, D. rapae is used as a biological control agent against the Russian wheat aphid (Diuraphis noxia) which feeds on cultivated grasses in the western United States. Thus, D. rapae has a choice between two aphid hosts where these plant types are grown together. To assess whether this situation may lead to population differentiation we examined the genetic structure of this parasitoid on a microgeographical scale within managed agricultural systems in northern Colorado.

\section{Materials and methods}

\section{Study organisms}

Diaeretiella rapae is a solitary endoparasitoid of many aphid species (Vater, 1971; Stary, 1976) with adult females laying a single egg directly into an aphid's body. The parasitized aphid continues to feed for 3-4 days and typically remains in the same location after being attacked. Diaeretiella rapae progresses through four larval instars as it feeds on the internal tissues of the aphid, eventually killing it. When the host dies it becomes a mummy consisting of the hardened exoskeleton of the aphid. The wasp pupates within the aphid host and emerges from the mummy as an adult. Under laboratory conditions $\left(20^{\circ} \mathrm{C} ; 60\right.$ per cent $\left.\mathrm{RH}\right)$, egg to adult development requires $\approx 9$ days.

In northern Colorado, two aphid species are commonly attacked by $D$. rapae, the cabbage aphid (Brevicoryne brassicae) and Russian wheat aphid. Both aphid species are serious pests to agricultural crops: B. brassicae feeds exclusively on crucifer crops and $D$. noxia feeds exclusively on cultivated cereals. Crucifer crops and cereal crops are grown in close proximity to each other in some regions whereas in other regions, cereal crops, mainly dryland wheat, are grown in extensive monoculture. This scenario affords $D$. rapae the opportunity to parasitize two aphid hosts which may be separated by many kilometres or as little as several metres.

\section{Field collections}

Wasps were collected from crucifer vegetable crops and from cultivated cereal crops in northern Colorado. Individual wasps were removed from aphid colonies on host plants by gently brushing the mummified aphids individually into gelatin capsules. Aphid mummies were collected rather than adult wasps to ensure that the wasps analysed were the progeny of adult females that located and chose to parasitize a particular aphid in a particular location. Aphid mummies were returned to the laboratory, were maintained at $23^{\circ} \mathrm{C}$ until the adults emerged, then were sexed and frozen at $-80^{\circ} \mathrm{C}$.

A hierarchical sampling design was used to collect D. rapae populations from six fields within three regions of northern Colorado (Table 1). Within each region, we located two aphid-infested fields less than $1.0 \mathrm{~km}$ from each other. Region I was located at Piedmont Farms, an organic vegetable production area. The two wasp populations collected from this area were sampled from Brussels sprouts and winter wheat, separated by $0.25 \mathrm{~km}$. Region II was located $23 \mathrm{~km}$ south-east of Region I. The populations sampled in this region were located on $4 \mathrm{~V}$ Farms, a cereal production farm in Weld County. Both $D$. rapae populations were collected from winter wheat fields separated by $0.50 \mathrm{~km}$. Region III was located $12 \mathrm{~km}$ south-east of Region I and $18 \mathrm{~km}$ south-west of Region II. The two populations collected in this region were $1.0 \mathrm{~km}$ apart and were collected from a winter wheat field and a cabbage field.

Each of the six populations was sampled three times per year (June, July and August) in 1994 and 1995 to test for seasonal differences in population 
Table 1 Sampling locations for Diaeretiella rapae populations in Colorado in 1995 and 1996

\begin{tabular}{lllcc}
\hline Region & $\begin{array}{c}\text { Population } \\
\text { location }\end{array}$ & Field type & $\begin{array}{c}\text { Distance from } \\
\text { region I (km) }\end{array}$ & $\begin{array}{c}\text { Distance between fields } \\
\text { within each region }(\mathrm{km})\end{array}$ \\
\hline I & Piedmont Farms & Wheat & 0 & \\
I & Piedmont Farms & Crucifer & 0 & 0.25 \\
II & Weld County & Wheat & 23 & \\
II & Weld County & Wheat & 23 & 0.05 \\
III & Hort Farms & Crucifer & 13 & 1.0 \\
III & BARI & Wheat & 12 & \\
\hline
\end{tabular}

structure. For each sampling period, 46 individuals were analysed ( 23 males and 23 females). The field sampling procedure followed a modified version of Quick Sample, a tool for determining Russian wheat aphid infestations in cereal fields (Legg et al., 1991). Fields were entered at one corner and a plant was sampled for $D$. rapae mummies every 10-20 paces. Only one wasp mummy was collected from any plant. This procedure ensured that the entire field was sampled and reduced the chance of collecting several progeny from a single female wasp.

\section{DNA extraction, RAPD-SSCP and electrophoresis}

DNA was isolated from individual wasps following the protocol of Coen et al. (1982). DNA was resuspended in $100 \mu \mathrm{L}$ TE $(10 \mathrm{~mm}$ TRIS-HCl, $1 \mathrm{~mm}$ EDTA, $\mathrm{pH} 8.0$ ) and $1 \mu \mathrm{L}$ of DNA template was used in each $50 \mu \mathrm{L}$ PCR reaction. Details of the RAPD-PCR protocols can be found in Black et al. (1992) and details of the SSCP (Single Strand Conformational Polymorphisms) analysis can be found in Hiss et al. (1994) and Antolin et al. (1996b). Each set of PCR reactions was checked for contamination by using a negative control (all reagents except template DNA). Samples were stored at $4^{\circ} \mathrm{C}$ until being electrophoresed.

Complete details of the polyacrylamide gel electrophoresis (PAGE) procedure are described in Hiss et al. (1994) and Black \& DuTeau (1996). Modifications to this procedure are in Antolin et al. (1996b). Briefly, PCR products $(5 \mu \mathrm{L}$ of a $50 \mu \mathrm{L}$ sample) were mixed with $2 \mu \mathrm{L}$ loading buffer at room temperature. The products were electrophoresed on large $(40 \times 50 \mathrm{~cm})$, thin $(0.4 \mathrm{~mm})$ glycerol $(5$ per cent) polyacrylamide ( 5 per cent, 2 per cent cross-linking) gels. Samples $(5 \mu \mathrm{L})$ were loaded into $6 \mathrm{~mm}$ sharkstooth combs. Electrophoresis proceeded at constant voltage $(350 \mathrm{~V})$ at room temperature for
$15 \mathrm{~h}$. The gels were subsequently stained using silver to detect the mobility of the different DNA markers.

\section{Segregation analysis of RAPD-SSCP markers}

The majority of RAPD markers are expressed as phenotypically dominant markers in diploid organisms. However, because of the high resolution offered by the PAGE technique, SSCP procedures, and the haplo-diploid sex determination in Hymenoptera, we have also identified numerous codominant markers using a segregation analysis. Inheritance of the bands was tested by generating full-sib families from each of the field populations. Two families were created for each of the two Piedmont populations and one family was created for the remaining four populations. Diaeretiella rapae families were produced by collecting individuals as mummies and rearing them in an incubator $\left(25^{\circ} \mathrm{C}\right.$, 60 per cent $\mathrm{RH}$ ). Upon emergence, mated pairs were formed and the females allowed to oviposit on an aphid-infested plant for $24 \mathrm{~h}$. The mated pair was then stored at $-80^{\circ} \mathrm{C}$. The progeny were individually collected as mummies, allowed to emerge as adults and also stored at $-80^{\circ} \mathrm{C}$. These families were screened with 18 RAPD primers. We chose the following four primers from Operon Technologies: A05, C01, C04 and BAMH1 (5'-ATGGATCCGC-3', designed by N. M. DuTeau, Colorado State University) with which to test Mendelian inheritance patterns. Repeatability was then tested by amplifying the DNA of each individual in each family twice.

Amplified markers were scored directly from dried gels by measuring band mobility relative to known size markers ( $1 \mathrm{~kb}$ ladder, BRL Laboratories). To estimate sizes of the amplified DNA fragments, size standards were fitted to an inverse function that relates fragment size and mobility (Schaffer \& Sederoff, 1981). Each marker was 
labelled by the primer used in the PCR reaction and by its mobility on the gel (e.g. A05.275).

\section{Analysis of population subdivision}

The RAPD-PCR markers generated from our fieldcollected populations were analysed in two ways. The most commonly used methods to estimate population subdivision are Wright's $F$-statistics and related estimates (Wright, 1978; Cockerham \& Weir, 1993; Slatkin, 1993). These indices measure the correlation between alleles found in subpopulations, relative to the population as a whole. $F_{\text {ST }}$ represents the standardized variance in allele frequencies among local populations and ranges between 0 , indicating no genetic differentiation, and 1 , indicating complete differentiation. In order to calculate $F_{\mathrm{ST}}$ from dominant RAPD markers, it must be assumed that populations are in Hardy-Weinberg equilibrium. However, by examining the frequencies of the codominant alleles from the female samples, the assumption of Hardy-Weinberg could be explicitly tested. We used the computer program BIOSYs-1 (Swofford \& Selander, 1981) and a chi-squared analysis to test for deviations from Hardy-Weinberg equilibrium for each codominant RAPD marker.

Estimates of $F_{\mathrm{ST}}$ and effective migration rates $(\mathrm{Nm})$ among the females in each population $(n=23)$ were calculated using the computer program RAPDFST provided by W. C. Black IV (Department of Microbiology, Colorado State University, see Appendix). The program calculates standard $F_{\mathrm{ST}}$ and effective migration rates (Wright, 1978) as well as estimates corrected for small sample sizes (Cockerham \& Weir, 1993) and for both small sample sizes and the effects of dominant loci commonly detected by RAPD-PCR (Lynch \& Milligan, 1994).

\section{Linkage disequilibrium}

Linkage disequilibrium describes the nonrandom association of alleles (Lewontin \& Kojima, 1960) and can arise in subdivided populations from epistatic natural selection within subpopulations (Lewontin, 1974, pp. 273-318), random genetic drift among subpopulations (Ohta \& Kimura, 1969) or actual linkage among the markers. Di-locus linkage disequilibrium was estimated using RAPDLD (Black, 1995; Apostol et al., 1996; see Appendix) which estimates linkage disequilibrium among RAPD alleles in the subpopulations.

\section{Genetic distance}

The second method of analysis was based upon pairwise genetic distances between populations, which does not depend upon the assumption of population equilibrium (Slatkin, 1993). The number of markers generated with RAPD-PCR allowed us not only to estimate genetic distances but also to perform robust statistical analyses of population subdivision at smaller spatial scales. In conjunction with W. C. Black IV, a computer program called RAPDDIST (Black \& Antolin, see Appendix) was developed that uses RAPD data to estimate genetic distances for haploid and diploid organisms. Nei's unbiased genetic distances (Nei, 1978) between pairs of populations were then submitted to PHYLIP 3.5c (Felsenstein, 1995) to create cluster diagrams (trees) based upon UPGMA, an unweighted pair-group method with arithmetic averaging clustering analysis (Avise, 1994). RAPDDIST further allows for statistical testing of individual branches on the trees by resampling the data, thus testing for consistency within the RAPD data set in forming the observed groupings. Each sex was analysed separately for each sampling date and also by combining all sampling dates.

\section{Results}

\section{Segregation analysis}

The four primers generated a total of 34 dominant (presence/absence) markers and 11 codominant markers in the families, all of which were polymorphic and had an observed frequency of less than 0.92, as recommended by Lynch \& Milligan (1994). Primer A05 produced 11 dominant and four codominant markers, $\mathrm{C} 01$ produced nine dominant and three codominant markers, C04 produced eight dominant and three codominant markers and BAMH1 produced six dominant and one codominant marker (Table 2). Repeatability was verified by reamplifying the DNA of each individual in each family with all four primers a second time and identifying the same markers. The inheritance of each marker conformed to Mendelian segregation patterns among the full-sib families. Figure 1 demonstrates common patterns found in the segregation of RAPD-PCR markers. Mendelian inheritance of codominant RAPD markers for haplodiploid families can be determined as follows: if a female having a fast and slow allele is mated to a male with a slow allele, the male offspring will have either a fast or a slow allele and the female offspring will be either heterozygous or homozygous for the 
slow allele (Fig. 1a). In the case of a dominant marker, if a female homozygous for the null allele (no band present) is mated to a male that carries a copy of the allele, none of the male offspring will show the marker but all of the female offspring will have a copy because they developed from fertilized eggs (Fig. 1b).

\section{Estimation of population subdivision}

Deviations from Hardy-Weinberg equilibrium were tested for each of the 11 codominant loci in each of the six populations using the female wasps. No deviations from Hardy-Weinberg equilibrium were found (all $\chi_{1}^{2}<3.33 ; P>0.10$ ) except for one locus in the population obtained from BARI $\left(\chi_{1}^{2}=3.94\right.$; $P<0.05)$. However, this was not significant when the variances were adjusted using Bonferroni corrections $(P>0.13)$. The mean heterozygosity, averaged across sample dates and RAPD loci for each population was calculated and ranged from 0.335-0.443 (Table 3).
All three estimates of population subdivision were similar in this study for males and females combined: $F_{\mathrm{ST}}$ estimated from Wright (1951) was 0.066 in 1994 and 0.073 in $1995(P<0.01)$; Weir \& Cockerham's $\theta$, which accounts for small sample sizes, was estimated as 0.063 in 1994 and 0.070 in 1995; and $F_{\mathrm{ST}}$ estimated from Lynch \& Milligan (1994), whose method accounts for small and unequal sample sizes and dominance effects inherent with RAPD loci, was estimated at 0.061 in 1994 and 0.069 in $1995 . F_{\mathrm{ST}^{-}}$and $\theta$-values for each sampling date are given in Table 4.

The data set was subjected to a nested analysis of variance following Wright (1978) using BIOSYS-1 (Swofford \& Selander, 1981) to determine the level at which the populations were genetically subdivided. Variance components indicate that most of the variation within the population occurred between fields rather than between the areas containing the fields for all sampling dates in each year (Table 5). The effective migration rates obtained for all populations for 1994 and 1995 were quite low at 1.2 and 1.6 wasps per year, respectively.

Table 2 Frequency of RAPD markers for all six Diaeretiella rapae populations for females and males for each year. Shown are the frequencies for the band-present alleles for the dominant markers and the 'fast' alleles for the codominant markers (denoted by *)

\begin{tabular}{|c|c|c|c|c|c|c|c|c|c|}
\hline \multirow[b]{2}{*}{ Marker } & \multicolumn{2}{|c|}{1994} & \multicolumn{2}{|c|}{1995} & \multirow[b]{2}{*}{ Marker } & \multicolumn{2}{|c|}{1994} & \multicolumn{2}{|c|}{1995} \\
\hline & Female & Male & Female & Male & & Female & Male & Female & Male \\
\hline A05.275 & 0.861 & 0.842 & 0.755 & 0.701 & C01.372 & 0.667 & 0.690 & 0.717 & 0.966 \\
\hline A05.320* & 0.694 & 0.667 & 0.761 & 0.696 & C01.415 & 0.283 & 0.370 & 0.304 & 0.396 \\
\hline A05.380 & 0.619 & 0.671 & 0.543 & 0.630 & C01.425 & 0.333 & 0.310 & 0.239 & 0.283 \\
\hline A05.465 & 0.521 & 0.474 & 0.590 & 0.523 & C01.452 & 0.543 & 0.652 & 0.478 & 0.578 \\
\hline A05.486 & 0.385 & 0.425 & 0.467 & 0.511 & C01.569 & 0.696 & 0.743 & 0.657 & 0.701 \\
\hline A05.496 & 0.306 & 0.286 & 0.304 & 0.413 & C01.597 & 0.667 & 0.723 & 0.698 & 0.723 \\
\hline A05.585 & 0.717 & 0.697 & 0.755 & 0.722 & C01.635* & 0.583 & 0.501 & 0.555 & 0.497 \\
\hline A05.620 & 0.239 & 0.282 & 0.360 & 0.392 & C01.791 & 0.534 & 0.611 & 0.567 & 0.623 \\
\hline A05.682* & 0.861 & 0.810 & 0.752 & 0.796 & C01.815* & 0.457 & 0.399 & 0.489 & 0.409 \\
\hline A05.761* & 0.500 & 0.432 & 0.564 & 0.499 & C01.1217* & 0.472 & 0.569 & 0.512 & 0.577 \\
\hline A05.820 & 0.417 & 0.476 & 0.289 & 0.334 & C01.1615 & 0.389 & 0.443 & 0.355 & 0.452 \\
\hline $\mathrm{A} 05.855^{*}$ & 0.652 & 0.718 & 0.578 & 0.591 & C01.2376 & 0.826 & 0.761 & 0.773 & 0.697 \\
\hline A05.894 & 0.804 & 0.761 & 0.891 & 0.800 & C04.289 & 0.306 & 0.286 & 0.327 & 0.291 \\
\hline A05.975 & 0.572 & 0.611 & 0.609 & 0.701 & C04.351 & 0.778 & 0.786 & 0.696 & 0.775 \\
\hline A05.1254 & 0.279 & 0.299 & 0.317 & 0.342 & C04.415* & 0.472 & 0.515 & 0.505 & 0.543 \\
\hline BAMH1.331 & 0.196 & 0.174 & 0.231 & 0.202 & C04.496 & 0.217 & 0.330 & 0.256 & 0.342 \\
\hline BAMH1.415 & 0.239 & 0.196 & 0.341 & 0.225 & C04.544 & 0.348 & 0.477 & 0.389 & 0.514 \\
\hline BAMH1.497 & 0.712 & 0.784 & 0.754 & 0.798 & $\mathrm{C} 04.565$ & 0.696 & 0.772 & 0.819 & 0.832 \\
\hline BAMH1.532 & 0.543 & 0.652 & 0.603 & 0.687 & C04.705* & 0.286 & 0.378 & 0.396 & 0.403 \\
\hline BAMH1.615 & 0.457 & 0.340 & 0.514 & 0.448 & C04.967 & 0.222 & 0.298 & 0.201 & 0.279 \\
\hline BAMH1.732* & 0.513 & 0.599 & 0.609 & 0.623 & C04.1170* & 0.592 & 0.501 & 0.611 & 0.577 \\
\hline \multirow[t]{2}{*}{ BAMH1.825 } & 0.876 & 0.778 & 0.765 & 0.698 & C04.1852 & 0.761 & 0.744 & 0.679 & 0.778 \\
\hline & & & & & C04.2005 & 0.577 & 0.523 & 0.613 & 0.549 \\
\hline
\end{tabular}




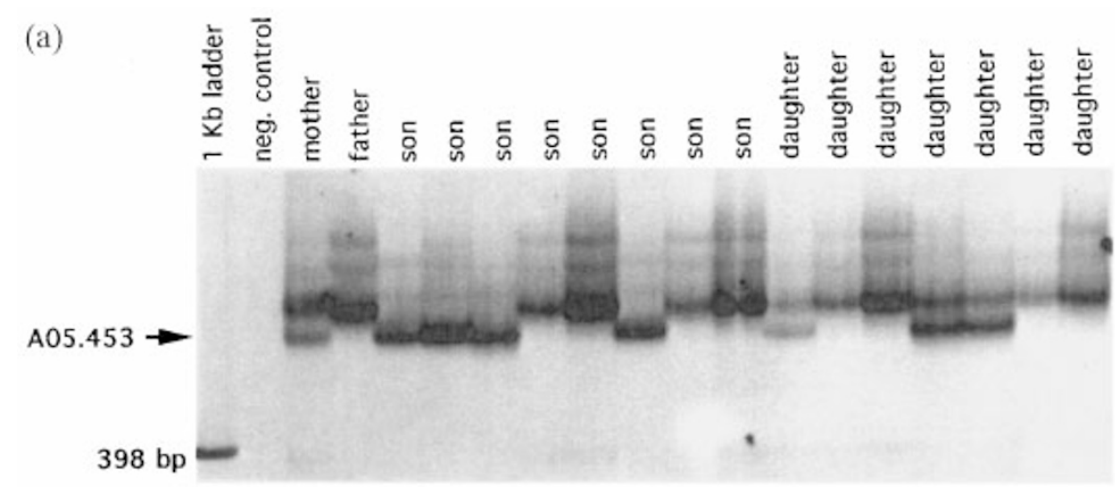

(b)

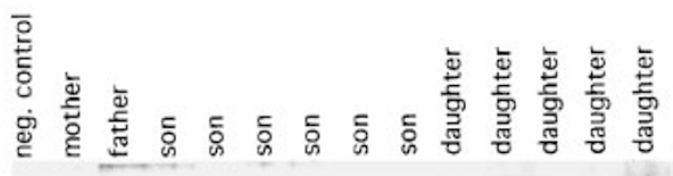

Fig. 1 Examples of silver-stained PAGE gels demonstrating the inheritance patterns of (a) codominant RAPD-PCR markers and (b) dominant RAPD-PCR markers in Diaeretiella rapae. See text for details of haplo-diploid Mendelian inheritance patterns.

\section{Linkage disequilibrium}

With 34 RAPD loci there were 561 [ $(34 \times 33) / 2]$ pair-wise comparisons made to estimate linkage disequilibrium. The amount of linkage disequilibrium detected in any population was less than 3 per cent and in no population was this amount significant at $\alpha=0.05$. This analysis indicates that the RAPD markers used in this study were not linked with one another.

Table 3 Mean heterozygosity for the 11 codominant alleles (two alleles per locus) averaged across sample dates and RAPD loci for each population of Diaeretiella rapae. Numbers in parentheses indicate standard errors

\begin{tabular}{lc}
\hline Population & Heterozygosity \\
\hline Piedmont wheat & $0.335(0.045)$ \\
Piedmont crucifer & $0.416(0.024)$ \\
Weld wheat I & $0.443(0.030)$ \\
Weld wheat II & $0.425(0.039)$ \\
Hort Farms crucifer & $0.392(0.024)$ \\
BARI wheat & $0.412(0.055)$ \\
\hline
\end{tabular}

\section{Cluster analysis}

Cluster diagrams were generated for each sex for each sample date and for each sex for all sample dates combined for each year. There were no differences between the trees generated for males or females at any sampling date and there were no significant differences in topology between sample dates within either sex using strict consensus $(>50$ per cent grouping). Trees generated using females from all sampling dates within 1994 and 1995 are shown in Fig. 2. Although there is weak support for population subdivision among areas (e.g. Piedmont

Table 4 Estimates of $F_{\mathrm{ST}}$ and $\theta$ for Diaeretiella rapae by date for 1994 and 1995

\begin{tabular}{|c|c|c|c|c|c|c|}
\hline \multirow{2}{*}{$\begin{array}{l}\text { Sampling } \\
\text { date }\end{array}$} & \multicolumn{2}{|c|}{$F_{\mathrm{ST}}(\mathrm{W})$} & \multicolumn{2}{|c|}{$\theta$} & \multicolumn{2}{|c|}{$F_{\mathrm{ST}}(\mathrm{L} \& \mathrm{M})$} \\
\hline & 1994 & 1995 & 1994 & 1995 & 1994 & 1995 \\
\hline June & 0.070 & 0.065 & 0.060 & 0.068 & 0.064 & 0.071 \\
\hline July & 0.059 & 0.071 & 0.058 & 0.062 & 0.056 & 0.063 \\
\hline August & 0.066 & 0.074 & 0.070 & 0.073 & 0.061 & 0.069 \\
\hline
\end{tabular}

(W), Wright; (L \& M), Lynch \& Milligan. 
Table 5 Variance components combined across loci from the nested analysis of variance for Diaeretiella rapae populations collected in Colorado during 1994 and 1995

\begin{tabular}{llrr}
\hline \multirow{2}{*}{$\begin{array}{l}\text { Sampling } \\
\text { date }\end{array}$} & & \multicolumn{2}{c}{ Variance components } \\
\cline { 3 - 4 } & Comparison & 1994 & 1995 \\
\hline June & Fields within regions & 0.619 & 0.613 \\
& Fields within the total & 0.424 & 0.501 \\
& Regions within the total & -0.035 & -0.059 \\
July & Fields within regions & 0.771 & 0.690 \\
& Fields within the total & 0.301 & 0.405 \\
& Regions within the total & -0.070 & -0.013 \\
August & Fields within regions & 0.809 & 0.771 \\
& Fields within the total & 0.299 & 0.316 \\
& Regions within the total & -0.094 & -0.073 \\
\hline
\end{tabular}

Farms wheat and crucifer populations vs. Weld County wheat populations, Fig. 2a), complete support is given only to each branch that includes the same fields in two different years except for Weld County populations (Fig. 2b). The Weld County populations group together within the same year for both 1994 and 1995. Interestingly, crucifer fields (Piedmont Farms and Hort Farms) remained genetically distinct from nearby wheat fields (Piedmont Farms and BARI), although they were less than $1.0 \mathrm{~km}$ from each other.

\section{Discussion}

The habitats of most insect species are heterogeneous and discontinuous in time and space and typically contain patches that provide essential resources such as food or reproduction sites (Elton, 1949; Southwood, 1977). In such cases, gene flow between populations can be restricted because individuals tend to move mainly within physically or otherwise separated habitats that contain essential resources. In many invertebrates, a combination of limited dispersal and habitat fidelity results in marked population subdivision, sometimes even over small geographical distances. For example, population substructuring on a microgeographical scale has been demonstrated in a wide variety of organisms, showing that gene flow is often extremely limited, even over relatively short distances (Bilton, 1992; Rank, 1992; Seppa \& Pamilo, 1995; Apostol et al., 1996; West, 1996). Resource fragmentation may be common in agricultural systems, especially in parasitoid-host interactions where more than one host type is available. Thus, the diverse habitat encoun- tered by parasitoids in agricultural environments may cause population differentiation.

This study of the population genetic structure of D. rapae is one of the first studies to demonstrate genetic differentiation in a parasitoid or biological control agent. Because of its use as a biocontrol agent, the biology of this wasp has been extensively studied. However, most of the research conducted on this wasp has concentrated on how it locates aphid hosts (Read et al., 1970; Ayal, 1987; Sheehan \& Shelton, 1989b), especially with reference to chemical cues (Sheehan \& Shelton, 1989a; Reed et al., 1991; Vaughn et al., 1996). Diaeretiella rapae is attracted to the volatiles emitted from crucifer plants and may possess specialized receptors used in locating habitats with these plant volatiles. Yet, $D$. rapae parasitizes many other aphid species not found on crucifer plants. In this study, the population structure of $D$. rapae was examined with particular reference to habitat types which occur in diverse agricultural systems.

One of the difficulties encountered in population genetic studies, especially of Hymenoptera, is the level of resolution offered by indirect estimates of gene flow. With the advent of RAPD-PCR technology, it is now possible to estimate differentiation of populations on a relatively small spatial scale because of the large number of genetic polymorphisms. In addition, the use of large polyacrylamide gels combined with the greater resolution of silver staining made the analysis of these polymorphisms far easier and more accurate than other methods of detecting genetic differences between populations. If the inheritance patterns of RAPD-PCR markers can be established as we have shown in this study, these 
markers become as effective as any other genetic marker used in population-level studies (Carlson et al., 1991; Hunt \& Page, 1992; Apostol et al., 1993; Fondrk et al., 1993; Mitchell-Olds, 1995; Antolin et al., 1996a,b). The use of genetic markers such as RAPDs also tests whether the entire genome supports the observed groupings rather than just a few loci. This is further supported because none of the RAPD markers was in significant linkage disequilibrium with another.

The estimates of population subdivision via Wright's $F$-statistics certainly indicate that the $D$. rapae population is subdivided. The methods of Wright (1951), Weir \& Cockerham (1984) and
Lynch \& Milligan (1994) all produced similar estimates of population differentiation. Furthermore, the $F_{\mathrm{ST}}$-values and variance components indicate that most of the variation in northern Colorado occurs between fields rather than between areas containing the fields, for all sampling dates within each year. Thus, the individual fields within an area are as different from each other as are fields in different areas, even though pairs of fields within any area are separated by $1 \mathrm{~km}$ or less and areas are separated by as much as $23 \mathrm{~km}$ (Fig. 2b). In addition, the comparisons of sampling dates within each year indicate that the subdivision among populations is maintained from year to year, even in small

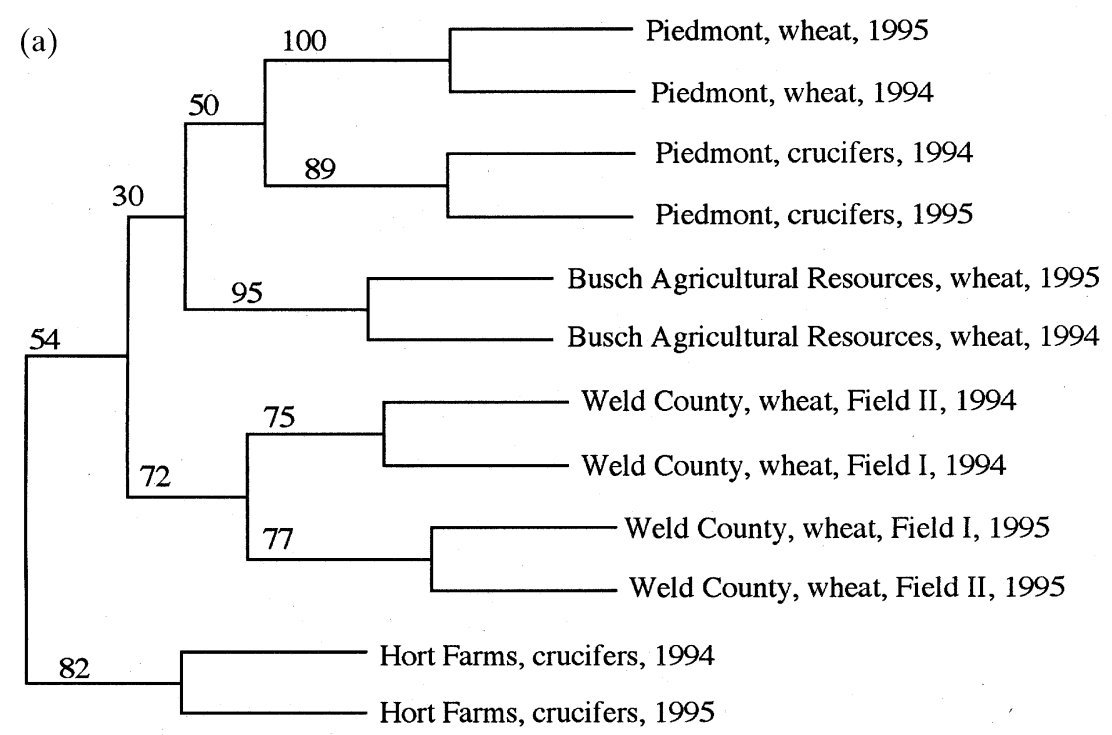

Fig. 2 Cluster diagrams showing the structure of Diaeretiella rapae female populations in Colorado. Shown are Nei's standard genetic distances among populations of individuals collected during August 1994 and 1995. At each branching point is indicated the bootstrap support (out of 100) for that branch. (a) The pattern indicates that the population of $D$. rapae in northern Colorado is subdivided into many smaller populations, probably a result of limited dispersal, even between fields that are less than $1.0 \mathrm{~km}$ from each other (Piedmont wheat fields vs. Piedmont crucifer fields). (b) After collapsing the branching points with low support (fewer than 75 times out of 100), the pattern still indicates that fields are different from one another.

(b)

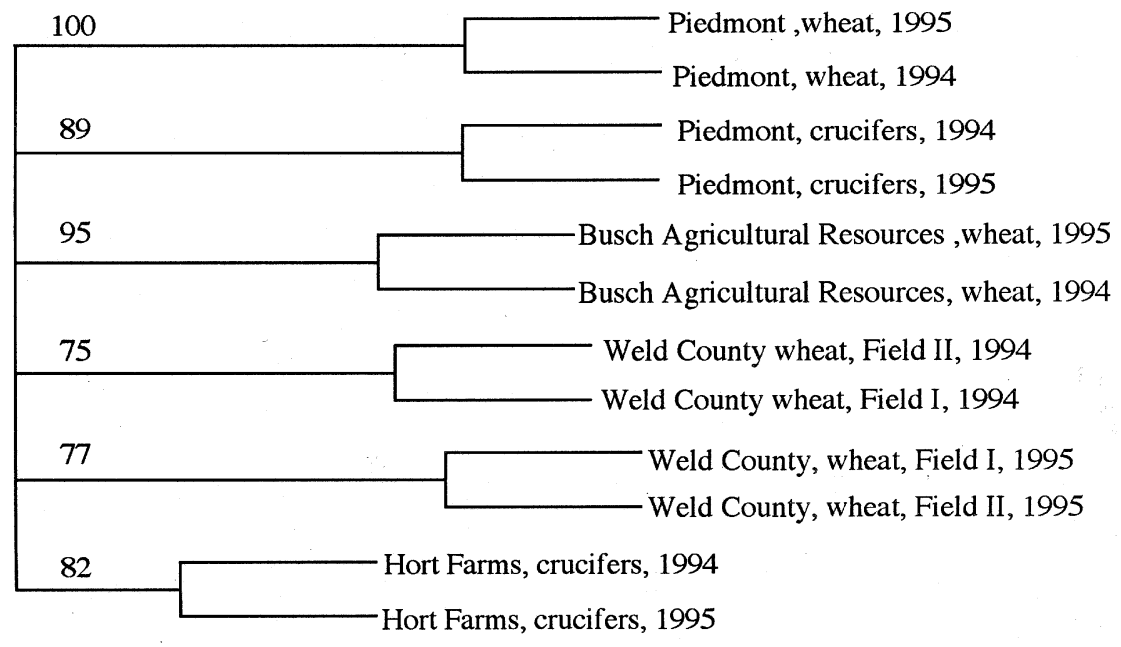


geographical areas, and does not depend on recolonization each year.

The analysis of the genetic distances between populations also demonstrates that the population is structured in the agricultural environment. These results indicate that once wasps locate habitats with aphids, they remain in those areas and disperse less than $1 \mathrm{~km}$, whether those habitats are wheat fields or crucifer fields. However, the two populations from the Weld County wheat fields appear to be more homogeneous (Fig. 2). The two fields group within the same year for both years and the internal node grouping the Weld County Region is high. This has important implications for biological control programmes where wasps are released each year. For example, if there are no ameliorating factors involved, $D$. rapae will most likely remain in the specific fields where the releases occur and have low migration rates between fields. Indeed, field observations and previous work with $D$. rapae in flight tunnels (Sheehan \& Shelton, 1989a; Vaughn et al., 1996), showed that these wasps have a low tenacity for sustained flight, and spend most of their time at or below the vegetation canopy.

Although there are numerous studies of herbivorous insect populations that demonstrate genetic subdivision at small spatial scales (McCauley \& Eanes, 1987; McCauley et al., 1988; McPheron et al., 1988; Guttman \& Weigt, 1989; Guttman et al., 1989; Rank, 1992), this is the first study of a parasitoid wasp to demonstrate genetic subdivision. Predatory lady beetles (Coleoptera: Coccinellidae) are the only natural enemies whose population structure has been studied extensively (Krafsur et al., 1992, 1995; Steiner \& Grasela, 1993; Coll et al., 1994). These studies employed allozyme electrophoresis to examine gene flow and the main conclusion drawn from each study was that the lady beetle population was not subdivided, even between states in some cases. This suggests that the high mobility of coccinellids contributes to their effectiveness as biological control agents. A recent study using allozymes, however, has demonstrated genetic subdivision between Hawaiian populations of the coccinellid Curinus coeruleus (Follett \& Roderick, 1996). The levels of gene flow found in this system are similar to those found in our study.

For insects that inhabit heterogeneous environments, the association with patchily distributed resources has important consequences for the evolution of insects whose dispersal is limited. Because the greatest opportunity for genetic variation in resource use occurs within patchy environments (Via \& Lande, 1985; Futuyma \& Philippi, 1989), migra- tion between local patches may cause conflicts that produce 'trade-offs' in performance unless the populations can adapt to different environments (Via \& Lande, 1985). The possibility of host adaptation is currently being investigated in these $D$. rapae populations.

\section{Acknow ledgements}

The authors wish to thank Piedmont Organic Farms for their co-operation and financial support for this project. We also thank Dr Whitney Cranshaw for access to field sites. The manuscript benefitted from comments by Dr Joan Herbers and two anonymous reviewers. This research was funded by The Organic Farming Research Foundation and Colorado Agricultural Experiment Station grant no. 697.

\section{References}

ANTOLIN, M. F. AND STRONG, D. R. 1987. Long-distance dispersal by a parasitoid (Anagrus delicatus, Mymaridae) and its host. Oecologia, 73, 288-292.

ANTOlin, M. F., GUertin, D. S. AND PETERSEN, J. J. 1996 a. The origin of gregarious Muscidifurax (Hymenoptera: Pteromalidae) in North America: an analysis using molecular markers. Biol. Control, 6, 76-82.

ANTOLIN, M. F., BOSIO, C. F., COTTON, J., SWEENEY, W., STRAND, M. R. AND BLACK, W. C., IV. 1996b. Intensive linkage mapping in a wasp (Bracon hebetor) and a mosquito (Aedes aegypti) with SSCP analysis of RAPD markers. Genetics, 143, 1727-1738.

APOSTOL, B. L., BLACK, W. C., IV, REITER, P. AND MILLER, B. R. 1996. Population genetics with RAPD-PCR markers: the breeding structure of Aedes aegypti in Puerto Rico. Heredity, 76, 325-334.

AVISE, J. C. 1994. Molecular Markers, Natural History and Evolution. Chapman and Hall, New York.

AYAL, Y. 1987. The foraging strategy of Diaeretiella rapae. I. The concept of the elementary unit of foraging. $J$. Anim. Ecol., 56, 1057-1068.

BILton, D. T. 1992. Genetic population structure of the postglacial relict diving beetle Hydroporus glabriusculus Aube (Coleoptera: Dytiscidae). Heredity, 69, 503-511.

BLACK, w. C. 1995. RAPDFST 3. 0 - A FORTRAN program to estimate Fst and effective migration rates among subpopulations using RAPD-PCR files. Department of Microbiology, Colorado State University, Ft. Collins, CO 80523, U.S.A.

BLACK, W. C. AND DUTEAU, N. M. 1996. RAPD-PCR and SSCP analysis for insect population genetic studies. In: Crampton, J., Beard, C. B. and Louis, C. (eds) The Molecular Biology of Insect Disease Vectors: A Methods Manual, pp. 361-373. Chapman and Hall, New York.

Black, W. C., DUteAU, N. M. PUTERKA, G. J., NECHOls, J. R. AND PETTORINI, J. M. 1992. Use of random amplified 
polymorphic DNA polymerase chain reaction (RAPDPCR) to detect DNA polymorphisms in aphids (Homoptera: Aphididae). Bull. Ent. Res., 82, 151-159.

CARLSON, J. E., TUlSIERAM, L. K., GLAUBitZ, J. C., LUK, v. W. K., KAUfFELDT, C. AND RUTLEDGE, R. 1991. Segregation of random amplified DNA markers in $\mathrm{F}_{1}$ progeny of conifers. Theor. Appl. Genet., 83, 194-200.

COCKERHAM, C. C. AND WEIR, B. s. 1993. Estimation of gene flow from $F$-statistics. Evolution, 47, 855-863.

COEN, E. S., STRAChAN, T. AND DOVER, G. 1982. Dynamics of concerted evolution of ribosomal DNA and histone gene families in the melanogaster species subgroup of Drosophila. J. Mol. Biol., 158, 17-35.

COLL, M., GARCIA DE MENDOZA, L. AND RODERICK, G. K. 1994. Population structure of a predatory beetle: the importance of gene flow for intertrophic level interactions. Heredity, 72, 228-236.

ELton, C. 1949. Population interspersion: an essay on animal community patterns. J. Ecol., 37, 1-23.

ENDler, J. A. 1986. Natural Selection in the Wild. Princeton University Press, Princeton, NJ.

FELSENSTEIN, J. 1995. PHYLIP: Phylogeny Inference Package. Version 3.5c. Department of Genetics, Box 357360, University of Washington, Seattle, WA 98195-7360, U.S.A.

FOLLETT, P. A. AND RODERICK, G. K. 1996. Genetic estimate of dispersal ability in the leucaena psyllid predator Curinus coeruleus (Coleoptera: Coccinellidae); implications for biological control. Bull. Ent. Res., 86, 355-361.

FONDRK, M. K., PAGE, R. E., JR. AND HUNT, G. J. 1993. Paternity analysis of worker honeybees using Random Amplified polymorphic DNA. Naturwissenschaften, 80, 226-231.

FUTUYMA, D. J. AND PHILIPPI, T. E. 1989. Genetic variation and covariation in response to host plants by Alsophila pometaria (Lepidoptera: Geometridae). Evolution, 41, 269-279.

GRAUR, D. 1985. Gene diversity in Hymenoptera. Evolution, 39, 190-199.

GUtTMAN, S. I. AND Weigt, L. A. 1989. Macrogeographic genetic variation in the Enchenopa binotata complex (Homoptera: Membracidae). Ann. Entomol. Soc. Am., 82, 225-231.

GUTTMAN, S. I., Wilson, T. AND Weigt, L. A. 1989. Microgeographic variation in the Enchenopa binotata complex (Homoptera: Membracidae). Ann. Entomol. Soc. Am., 82, 156-165.

HARTL, D. L. AND Clark, A. G. 1989. Principles of Population Genetics, 2nd edn. Sinauer, Sunderland, MA.

HAYMER, D. S. 1994. RAPDs and microsatellites: what are they and can they tell us anything we don't already know? Ann. Entomol. Soc. Am., 87, 717-722.

HISS, R. H., NORRIS, D. E., DIETRICH, C. H., WhITCOME, R. F., WEST, D. F., BOSIO, C. F. ET AL. 1994. Molecular taxonomy using single-strand conformation polymorphism (SSCP) analysis of mitochondrial DNA genes. Insect Mol. Biol., 3, 171-182.
HOPPER, K. R., ROUSH, R. T. AND POWELL, W. 1993. Management of genetics of biological-control introductions. Ann. Rev. Ent., 38, 27-51.

HUNT, G. J. AND PAGE, R. E. 1992. Patterns of inheritance with RAPD molecular markers reveal novel type of polymorphisms in the honey bee. Theor. Appl. Genet., 85, 15-20.

KRAFSUR, E. S., OBRYCKI, J. J. AND FLANDERS, R. V. 1992. Gene flow in populations of the seven-spotted lady beetle, Coccinella septempunctata. J. Hered., 83, 440-444.

KRAFSUR, E. S., OBRYCKI, J. J. AND SCHAEFER, P. W. 1995. Genetic heterozygosity and gene flow in Coleomegilla maculata De Geer (Coleoptera: Coccinellidae). Biol. Control, 5, 104-111.

LEGG, D. E., HeIN, G. L. AND PEAIRS, F. B. 1991. Sampling Russian Wheat Aphid in the Western Great Plains. Great Plains Agricultural Council, Pub. no. 138. Colorado State University Cooperative Extension.

LEWOnTIN, R. C. 1974. The Genetic Basis of Evolutionary Change. Columbia University Press, New York.

LEWONTIN, R. C. AND KOJIMA, K. 1960. The evolutionary dynamics of complex polymorphisms. Evolution, 14, $458-472$.

LYNCH, M. AND MILligAN, B. G. 1994. Analysis of population genetic structure with RAPD markers. Mol. Ecol., 3, 91-99.

McCAUley, D. E. AND EANES, W. F. 1987. Hierarchical population structure analysis of the milkweed beetle, Tetraopes tetraophthalmus (Forster). Heredity, 58, 193-201.

McCAULEY, D. E., WADE, M. J., BREDEN, F. J. AND WOHLTMAN, M. 1988. Spiral and temporal variation in group relatedness: evidence from the imported willow leaf beetle. Evolution, 42, 184-192.

MCPHERON, B. A., COURTNEY SMITH, D. AND BERLOCHER, $S$. H. 1988. Genetic differences between host races of Rhagoletis pomonella. Nature, 336, 64-66.

MITCHELL-OLDS, т. 1995. The molecular basis of quantitative genetic variation in natural populations. Trends Ecol. Evol., 10, 324-328.

MURDOCH, w. w. 1990. The relevance of pest-enemy models to biological control. In: Mackauer, M., Ehler, L. E. and Roland, J. (eds) Critical Issues in Biological Control, pp. 1-24. Intercept Ltd, Andover, U.K.

NEI, M. 1978. Estimation of average heterozygosity and genetic distance from a small number of individuals. Genetics, 89, 583-590.

RANK, N. E. 1992. A hierarchical analysis of genetic differentiation in a montane leaf beetle Chrysomela aeneicollis (Coleoptera: Chyromelidae). Evolution, 46, 1097-1111.

READ, D. P., FEENY, P. P. AND ROOT, R. B. 1970. Habitat selection by the aphid parasite Diaeretiella rapae (Hymenoptera: Braconidae) and hyperparasite Charps brassicae (Hymenoptera: Cynipidae). Can. Ent., 102, 1567-1578. 
REED, D. K., WEBSTER, J. A. JONES, B. G. AND BURD, J. D. 1991. Tritrophic relationships of Russian wheat aphid (Homoptera: Aphididae), a Hymenopterous parasitoid (Diaeretiella rapae M'intosh), and resistant and susceptible small grains. Biol. Control, 1, 35-41.

RODERICK, G. K. 1992. Post-colonization evolution of natural enemies. In: Kauffman, W. C. and Nechols, J. R. (eds) Selection Criteria and Ecological Consequences of Importing Natural Enemies, pp. 71-86. Thomas Say Publ., Entomol. Soc. America.

RODERICK, G. K. 1996. Geographic structure of insect populations: gene flow, phylogeography, and their uses. Ann. Rev. Ent., 41, 325-352.

SCHAFFER, H. E. AND SEDEROFF, R. R. 1981. Improved estimation of DNA fragment lengths from agarose gels. Analyt. Biochem., 115, 113-122.

SEPPA, P. AND PAMILO, P. 1995. Gene flow and population viscosity in Myrmica ants. Heredity, 74, 200-209.

SHEEHAN, w. AND SHELTON, A. M. 1989a. The role of experience in plant foraging by the aphid parasitoid Diaeretiella rapae (Hymenoptera: Aphidiidae). J. Insect Behav., 2, 743-759.

SheEhan, W. AND Shelton, A. M. 1989b. Parasitoid response to concentration of herbivore food plants: finding and leaving plants. Ecology, 70, 993-998.

SLATKIN, M. 1987. Gene flow and the geographic structure of natural populations. Science, 236, 787-792.

SLATKIN, M. 1993. Isolation by distance in equilibrium and non-equilibrium populations. Evolution, 47, 264-279.

SLATKIN, M. 1994. Gene flow and population structure. In: Real, L. A. (ed.) Ecological Genetics, pp. 3-17. Princeton University Press, Princeton, NJ.

southwood, T. R. E. 1977. Habitat, the template for ecological strategies? J. Anim. Ecol., 46, 337-365.

STARY, P. 1964. Food specificity in the Aphidiidae (Hymenoptera). Entomophaga, 9, 91-99.

Steiner, W. W. M. AND GRAsela, J. J. 1993. Population genetics and gene variation in the predator, Coleomegilla maculata (de Geer) (Coleoptera: Coccinellidae). Ann. Entomol. Soc. Am., 86, 309-321.

SWOFFORD, D. L. AND SELANDER, R. B. 1981. BIOSYS-1: $A$ FORTRAN program for the comprehensive analysis of electrophoretic data in population genetics and systematics. J. Hered., 72, 281-283.

van EMden, H. F. 1974. Pest Control and Its Ecology. Edward Arnold, London.

VATER G. VON 1971. Uber ubreitung und orientierung von Diaeretiella rapae (Hymenoptera: Aphididae). Z. Ang. Entomol., 68, 187-225.

VAUGhn, T. T., ANTOLIN, M. F. AND BJOSTAD, L. B. 1996. Behavioral and physiological responses of Diaeretiella rapae to semiochemicals. Entomologia exp. appl., 78, 187-196.

VIA, S. 1994. The evolution of phenotypic plasticity: what do we really know? In: Real, L. A. (ed.) Ecological Genetics, pp. 35-57. Princeton University Press, Princeton, NJ.

VIA, s. AND LANDE, R. 1985. Genotype-environment interaction and the evolution of phenotypic plasticity. Evolution, 39, 505-523.

WEIR, B. S. AND COCKERHAM, C. C. 1984. Estimating $F$-statistics for the analysis of population structure. Evolution, 38, 1358-1370.

WEst, D. F. 1996. Biology of snow-pool Aedes (Diptera: Culicidae) in Larimer County, Colorado. Ph.D. dissertation, Colorado State University.

WRIGHT, s. 1951. The genetical structure of populations. Ann. Eugen., 15, 323-354.

Wright, s. 1978. Evolution and Genetics of Populations, vol. 4, Variability Within and Among Natural Populations. University of Chicago Press, Chicago, IL.

\section{Appendix}

\section{Information on obtaining FORTRAN programs for analysis of RAPD-PCR data}

The programs are available by anonymous FTP file from Colorado State University and run in batch mode. Use the following steps to acquire the files via electronic mail (computer prompts appear in $<>$ ).

1. Once logged onto your network, type: ftp lamar.colostate.edu

2. < user: $>$ anonymous

3. < password: > your id

4. cd pub/wcb4

5. binary

6. dir

You will see rapds.zip. This contains a series of seven zip files that correspond with each of seven RAPD data analysis programs. The source code, executable code, a test dataset with output and documentation for each program are included.

7. To transfer a copy of the files, type: get rapds.zip

8. Once the programs are on your system, the files can be unzipped using PKUNZIP. 